\title{
Access to Archives in Post-Communist Countries: The Victim's Perspective
}

\section{Edita Gruodytè Silvija Gervienè}

Faculty of Law, Vytautas Magnus University Jonavos st. 66, Kaunas 44191, Lithuania E-mail: e.gruodyte@tf.vdu.It E-mail: silvijag29@gmail.com

Abstract: The collapse of the communist regime at the end of the twentieth century resulted in a wave of democratization in Central and Eastern Europe. While trying to establish democracy, many states in this region had to demonstrate their ability to protect human rights and to deal with the past of the repressive regime. As these states decided to join various human rights instruments they also became subject to certain obligations towards their people. One of these obligations is the requirement to provide remedies in case of human rights abuses, and the right to know the truth is recognized as part of it. Therefore the goal of this article is to identify the abilities of the victim of the communist regime to access the files of former secret services in post-communist countries in the light of the right to know the truth. The answer is provided using an analysis of international documents, historic, comparative and systemic methods, providing and evaluating the practice of different states dealing with the files of former secret services or government files of the repressive past and academic literature.

Keywords: files offormer secret services, post-communist countries, repressions, right to know the truth, victim 


\section{Introduction}

Respect for fundamental human rights is protected in every democratic state and entrenched in national, regional and international legal documents protecting human rights. However, human rights were seriously infringed during the communist regime which was in effect in many European states for a large part of the twentieth century. Furthermore, this regime is responsible for widespread and systemic repressions against millions of people, which resulted in serious human rights violations. After the collapse of the communist regime in the 1990 s, many post-communist countries ${ }^{1}$ faced and are still facing the problem of how to deal with the past. This is especially true in the case of redressing the victims of this regime.

Up until the end of the twentieth century, prosecution was emphasized over the rights of the victim (Aldana-Pindell, 2002, p. 1407). The most important step toward regulating victim's rights was the adoption of the Basic Principles and Guidelines on the Right to a Remedy and Reparation for Victims of Gross Violations of International Human Rights Law and Serious Violations of International Humanitarian Law (hereafter Basic Principles) by the General Assembly of the United Nations in 2005. The document is a manifestation of the existing victims' right to the effective remedies in case of serious abuses of human rights law and international humanitarian law. Notwithstanding the fact that this document is not legally binding, "the process has clearly put the issue on the international agenda... and may function as an element of emerging customary law on the issue" (Buyse, 2008). Therefore this document is given significant weight in the article.

An analysis of the practice of the European countries which have undergone transition from the repressive communist regime towards a democratic regime reveals that various approaches have been implemented dealing with the legacy of the repressive past. This is especially true in case of dealing with the files of former secret services. Access to them is required for the establishment of truth, especially since the activities of these services affected many lives in a tragically disturbing manner. Therefore the goal of this article is to identify the abilities of the victim of the communist regime (hereafter Victim) to access the files of former secret services (hereafter Files or Archives) in post-communist countries in the light of the right to know the truth.

1 The term "post-communist countries" is used in the article as covering both the European countries that were occupied and incorporated in the USSR, and the European countries that were only under influence of the USSR as in all these countries the communist regime was established. 
This paper has been structured into three sections. The first one analyzes whether the post-communist regime is treated as a gross violation of human rights as this is the only case when the Basic Principles are applicable. The second section deals with a Victim's right to know the truth, and possible instruments suggested or used for practical implementation. Further, the practice of the postcommunist countries, dealing with the Files is analyzed to determine if and how the Victim's right to information is implemented in practice. Taking into account the general goal of transition - that is, restoration of democracy and protection of human rights, it is doubtful whether restrictions regarding access to the Files are compatible with this goal.

\section{Communist repressions as a gross violation of human rights}

The communist regime was in effect in many countries of Central and Eastern Europe, as well as of Asia and Central America, for a large part of the twentieth century. With the collapse of the communist regime in Central and Eastern Europe, many countries faced the chance to move towards democratic regime and respect for human rights which also represented an attempt to deal with the past. However, it is evident that this was and still is not an easy task.

The communist regime has already been clearly condemned at the regional level. The Council of Europe addressed this question already in 1996 stating that "[t]he key to peaceful coexistence and a successful transition process lies in striking the delicate balance of providing justice without seeking revenge" (Council of Europe, 1996), and that addressing of former injustice in the postcommunist countries is the important right in providing justice. In the 2006 Resolution, this question is answered directly, providing that "totalitarian communist regimes [...] have been, without exception, characterized by massive violations of human rights", which, although to different degrees in each country, resulted in

individual and collective assassinations and executions, death in concentration camps, starvation, deportations, torture, slave labor and other forms of mass physical terror, persecution on ethnic or religious grounds, violation of freedom of conscience, thought and expression, of freedom of the press. (Council of Europe, 2006) 
In the year 2000, various non-governmental organizations, historians, lawyers and other socially active persons from 25 countries $^{2}$ established the anticommunist congress and public international tribunal to address the repressive past of the communist regime. After reviewing volumes of documents and hearing statements of many witnesses from different countries, this public tribunal established that the communist regime is responsible for war crimes, crimes against humanity, inter alia genocide, and crimes against peace. The communist regime was even named a tragedy equal to the Nazi regime, thus pointing to the need to address the issue on international level in the same manner as the Nazi regime. ${ }^{3}$

An important role in this question is played by the European Court of Human Rights (hereafter ECtHR, or the Court), where trials of former repressors of the communist regime were challenged on the grounds that they are incompatible with the principle nullum crimen, nullum poena sine lege. The Court recognized the right of former post-communist countries to prosecute persons responsible for the implementation of repressive policy if their acts constituted international crimes and found no reason to state otherwise in the light of the established facts. ${ }^{4}$

The scale and brutalities of atrocities of the communist regime are widely discussed in academic literature. One of the largest works on the general field of crimes under communist regime is The Black Book of Communism by Stéphane

2 Albania, Belarus, Bulgaria, Canada, Chechnya, Croatia, Estonia, Germany, Hungary, Italy, Israel, Japan, Kazakhstan, Kyrgyzstan, Latvia, Lithuania, Moldova, Poland, Romania, Russia, Slovakia, Sweden, and Ukraine.

3 See Anušauskas, Raudeliūnas, and Zabiela (2002) on all materials and documents on this anticommunist congress and public international tribunal.

4 E.g., in case of Streletz, Kessler and Krenz v. Germany [2001], the Court held that were was no violation of Article 7, Paragraph 1 if Germany tried and punished border guards responsible for the deaths of young people trying to escape the former GDR as both under national GDR law and under international law these acts constituted violations punishable as crimes. However, in this case after finding no violation of Article 7, Paragraph 1, the Court stated that "[i]n the light of that finding, the Court is not required to consider whether their convictions were justified under Article 7 $\S 2$ of the Convention." In the case Penart v. Estonia [2006], particular attention was given to the fact that "the Soviet Union was a party to the London Agreement of 8 August 1945 by which the Nuremberg Charter was enacted. Moreover, on 11 December 1946 the United Nations General Assembly affirmed the principles of international law recognized by the Charter. As the Soviet Union was a member state of the United Nations, it cannot be claimed that these principles were unknown to the Soviet authorities." The same result was reached in the case Kolk and Kislyiy v. Estonia [2006], where the applicants were found guilty of crimes against humanity because they had participated in the organization and implementation of the massive deportation operation "Priboi" in Estonia. 
Courtois and others (1999). More specific attention to the repressions of the Soviet period in Europe in line with the Nazi regime has been given by Timothy Snyder (2010). Issues in the Baltic States have been addressed in the works of Romuald J. Misiunas and Rein Taagepera (1993), Arvydas Anušauskas and others (2007). Soviet repressions (named as crimes against humanity) in Estonia and the Baltic states specifically have been discussed by Olaf Mertelsmann and Aigi Rahi-Tamm (2009), and Lauri Mälksoo (2001). The issue of mass deportations in Latvia as crimes against humanity has been studied by Katrina Inkuša (2009).

Therefore the question arises about the content of the duties towards Victims of such a regime.

\section{Victim's right to know the truth}

Up until the 1980s, the development of international human rights law was concerned with codification of fundamental rights of the accused in criminal procedures and almost no attention was given to the victims' rights (AldanaPindell, 2002, p. 1407). The duty of prosecution implemented by a state was emphasized and victim here appears as the one who is needed in prosecuting gross human rights violations, or "crimes against the individual's rights to life and personal integrity" (Aldana-Pindell, 2002, p. 1439).

The turn towards victim's perspective was inspired by the waves of democratization that started after the collapse of authoritarian regimes in South Europe (in the 1970s), of military regime in Latin America (in the 1980s), and finally the fall of the communist regime in Europe in the 1990s (Hansen, 2013). The victim's perspective revealed the importance of the truth in addressing human rights abuses and resulted in naming the truth as the primary demand of the victims (Parlevliet, 1998; Aldana-Pindell, 2002; David \& Choi Yuk-ping, 2005).

The victim's right to know the truth, in the context of addressing the past of communist regimes, is specifically grounded in Germany in Stasi Records Acts (in 1991) declaring that revelation of Files is important to "protect the individual from impairment of his right to privacy being caused by use of the personal data stored by the State Security Service" (Danielson, 2004). The Parliamentary Assembly of the Council of Europe in 1996 welcomed this measure and advised "countries concerned to enable the persons affected to examine, upon their request, the files kept on them by the former secret services" (Council of Europe, 1996, Supra note 2). 
The most important achievement by the international community towards the victim's rights is the acceptance of Basic Principles, as they are prepared from "victim-based perspective" and entail the whole picture of the victims' rights which is usually missing in traditional documents (Bassiouni, 2006). However, the right to know the truth is not something new, it just "again points to existing international law, thus not adding new norms" (Buyse, 2008, p. 141) as it has been recognized in international humanitarian law as early as in the 1949 Geneva Conventions and in jurisprudence of Human Rights Committee ${ }^{5}$ and Inter American Court of Human Rights (Antkowiak, 2002; Bassiouni, 2006; David, 2014). However, this right before the adoption of the Basic Principles was related with particular context of the repressive practice in Latin Americaforced disappearances, ${ }^{6}$ followed by torture and killing, to combat political opponents. As correctly explained by the Commission on Human Rights (2006, p. 5), "although this right was initially referred to solely within the context of enforced disappearances, it has been gradually extended to other serious human rights violations, such as extrajudicial executions and torture".

Victim's right to know the truth, together with access to justice and reparations, constitute the right to effective remedy (Basic Principles, 2005, Art. 3). Article 24 of Basic Principles specifically declares that

victims and their representatives should be entitled to seek and obtain information on the causes leading to their victimization and on the causes and conditions pertaining to the gross violations of international human rights law and serious violations of international humanitarian law and to learn the truth in regard to these violations. (Basic Principles, 2005, Art. 24)

5 As an example, M. Cherif Bassiouni (2006) provides the following cases: Case 11.481, Ignacio Ellacuria v El Salvador Report No. 136/99 [1999]; 8 IHRR 501 [2001] at Para. 221 (right to truth linked to the right to a remedy); Case 10.480, Lucio Parada Cea v El Salvador Report No. 1/99 [1998] at Para. 147 (right to know what happened, the reasons and the circumstances, as well as the participants). Valeska David (2014) provides an example of case law of Human Rights Committee in Almeida de Quinteros v. Uruguay, Hugo Rodriguez v. Uruguay, Amirov v. Russian Federation.

6 " $[\mathrm{F}]$ orced disappearance is considered to be the act of depriving a person or persons of his or their freedom, in whatever way, perpetrated by agents of the state or by persons or groups of persons acting with the authorization, support, or acquiescence of the state, followed by an absence of information or a refusal to acknowledge that deprivation of freedom or to give information on the whereabouts of that person, thereby impeding his or her recourse to the applicable legal remedies and procedural guarantees“"(OAS, 1994, Art. 1). 
Victim's right to know the truth is explained both as substantive and procedural right: the first aspect entails the right to know the truth about violations while the duty of state to employ all possible means for finding of truth is treated as the procedural right (Aldana-Pindell, 2002).

The same duality of the analyzed right is expressed in the study prepared by the Commission on Human Rights (2006). The procedural aspect is stressed by stating that it is "linked to the duty and obligation of the State to protect and guarantee human rights, to conduct effective investigations and to guarantee effective remedy and reparations" (Commission on Human Rights, 2006, p. 2). Substantive aspect of this right is explicated through linking it with other human rights such as the right to family life, the right to due process, the right to be free from torture and ill-treatment and the right to seek and impart information (Commission on Human Rights, 2006, p. 12).

As a result, victims are entitled to know the causes of personal victimization as well as causes for the whole system of human rights abuses, the circumstances of the particular violation, the fate and whereabouts of the persons who died in the course of violations and the identity of perpetrators - that is, the right to know the truth "should not be subject to limitations" (Commission on Human Rights, 2006, p. 15).

Possible instruments for disclosure of truth, such as international and national criminal proceedings, work of truth commissions or other investigating independent institutions, are suggested (Commission on Human Rights, 2006, pp. 13-14). However, suggested forms have both merits and deficiencies.

Establishment of truth in criminal proceedings safeguards procedural rights of the possible perpetrator. It is the only way for state participation in establishing the truth and delivering binding decisions which are lacking in usage of other forms as states usually refuse to recognize results reached by the established truth commissions or non-governmental organizations (Aldana-Pindell, 2002). Criminal proceedings are the best guarantee of non-repetition of gross human rights violations and a demonstration that such acts are not tolerated (Antkowiak, 2002).

However, criminal trials fail to reveal a broader picture of the whole system of repressions inflicted on a particular society, also it is impossible to address all cases of gross human rights violations in criminal trials because of lack of resources or because of strict standards of evidence (Antkowiak, 2002). Using this procedure, it is impossible to uncover all components of truth, taking into account the requirements of due process in criminal trials (Aldana-Pindell, 2002). 
The importance of truth commissions for determining truth is emphasized as they overcome provided drawbacks of criminal trials. As their primary function is fact-finding and not judging, the overall picture of gross human rights violations in their work is revealed, thus helping to understand the scale of the atrocities (Antkowiak, 2002). Additionally they are treated as a tool for educating and reconciling society after the repressive past (Teitel, 2000; Freeman, 2000-2002). However there is lack of evidence concerning their positive or negative impact to the victim's personal well-being (Antkowiak, 2002).

History reveals that many post-communist countries opted for such measures as prosecution of former activities under communist regimes, lustration and restitution of property as one of the possible forms of reparations (Teitel, 2000; Nalepa, 2010; Damsa, 2011; Hoffman, 2013; Liivoja, 2013) and are still dealing with the consequences of the communist regime. ${ }^{7}$ Some states established specific institutions to address and investigate the history of repressive periods. ${ }^{8}$

Notwithstanding the fact which of the described instruments is preferred by the state, "crucial to the exercise of the right to the truth is access to archives" (Commission on Human Rights, 2006, p. 14). Archives not only serve for personal disclosure of the truth including personal clarification concerning victimization (Miller, 1998; Danielson, 2004) but they are important sources of information both in criminal proceedings or for truth commissions as evidentiary materials but also important for formation of collective memory and performance of administrative task for victims to exercise their right to pension, rehabilitation, etc. (González-Quintana, 2009).

7 E.g., in Lithuania there are still ongoing trials concerning the genocide of Lithuanian partisans and deportation of civilian population after the Second World War (Delfi. $l t, 2014 ;$ Lrt.lt, 2014). In Poland, the restoration of former property rights, especially concerning ownership of the land, was temporally stopped in 2010 because of restitution claims submitted under civil law against the Agricultural Property Agency. For more information on this issue and implemented complex procedures concerning restoration of property rights in post-communist countries, see Hartvigsen, 2013.

8 E.g., The Genocide and Resistance Research Centre of Lithuania (LGGRTC) and International Commission for the Evaluation of the Crimes of the Nazi and Soviet Occupation Regimes in Lithuania were established in Lithuania. The Estonian State Commission on Examination of the Policies of Repression (ESCEPR) was founded in Estonia, the Commission of the Historians of Latvia-in Latvia and the Study Commission for Working through the History and the Consequences of the SED Dictatorship - in Germany. In Hungary, the corresponding institution was the Institute for the History of the 1956 Hungarian Revolution. For more information, see 'Truth commissions and similar bodies', 2013. 
Sensitivity of the contents of these archives inspires discussions regarding such issues as who should have access to them and how broad this given access should be (Guisse \& Joinet, 1993; Markovits, 2001; González-Quintana, 2009). The importance of the independent body in investigating archives and managing access is particularly stressed (Guisse \& Joinet, 1993). Critics have expressed that archives are used speculatively to gain advantages in the political arena (González-Quintana, 2009; Nalepa, 2010).

If and how this right is implemented in practice could be answered only after finding the details on how access to the Files is implemented in post-communist countries.

\section{Access to the archives in post-communist states}

The prevalent opinion in academic literature is that archives should be opened and the truth should be disclosed concerning the past repressive regimes in the defense of human rights (González-Quintana, 2009; Ciorciari, 2012; Stan, 2013). Some researchers have argued that the formation and preservation of archives is in the interest of the state and it is in the position to control access to various documents (Rosenberg, 2001), that is, the state is given wide discretion. However, it is inevitable that there is a conflict in such a case between right to access and right to privacy that must also be balanced with a public interest in reconstruction of a democratic state (Miller, 1998).

Notwithstanding different opinions, truth and the right to know this truth are related to the effective implementation of state obligations to ensure human rights and play an important role in providing remedies for victims of these violations. Therefore, there is a high demand for disclosure of truth as a means ensuring the obligation of state in the sphere of human rights. The analysis of the practice in European countries (which faced the communist regime in the past) reveals that states differ in the ways they have dealt with the Files, especially concerning the disclosure of these Files (Open Society, 2013), and thus could be divided into two categories: the countries providing full access, or those providing limited access. Full access to the Files is provided in such postcommunist countries as Bulgaria, the Czech Republic, Germany and Slovakia, while access with various limitations is imposed in such countries as Estonia, Hungary, Latvia, Lithuania, Poland and Romania.

Germany is usually treated as a positive example in dealing with the Files 
(Danielson, 2004; González-Quintana, 2009). In Germany, immediate and full access to the Files after the collapse of the communist regime was provided in 1991, while in other countries of this group full access was provided only after a certain period of time (Danielson, 2004; Stan, 2013). ${ }^{9}$ The aims of such policy were rebuilding of the confidence in state and its institutions, vindication of victim's rights, provision for the tool for lustration, information and education about the past (Miller, 1998).

In the model of full access, the Victim is able obtain information concerning his/her persecution, including the identity of collaborators. Such permission entails either direct examination or receiving copies of relevant documents or both. It is widely accepted that the information obtained by the Victim about his/her persecution is a sensitive one (Miller, 1998; Karstedt, 1998; Danielson, 2004). As a result, countries differ in the abilities that are provided for the Victims to deal with the information they obtained. ${ }^{10}$ Degree of access to information concerning collaborator varies, as in some countries the knowledge is restricted only to the name and surname of the

9 E.g., full access to the Files was provided in Slovakia in 2002, when Nation's Memory Act (2000) came into force. In Bulgaria only in 2006, after the Act on Access to and Disclosure of the Documents and Announcing Affiliation of Bulgarian Citizens with the State Security Service and the Intelligence Services of the Bulgarian National Army came into force (COMDOS, 2015). Full access to the Files was provided gradually in the Czech Republic. The first provisions governing limited access were introduced in 1996 and concerned only the Victims' abilities to access the Files. Significant changes were introduced in 2002 and 2004 (Banisar, 2007; BIC, 2009). The latest Act on the Institute for the Study of Totalitarian Regimes and the Security Services Archive, and on Amendments of some Acts, adopted in 2007, provided that final set of the Files, including agency, operative, investigation and cadre files or records, archive collections and individual archival materials and documents that resulted from the activity of security services and the Communist Party of Czechoslovakia and National Front organizations pursuing activity within the above bodies and services in the period from 4 April 1945 to 15 February 1990, must be transferred to the special archive for public access within five years from the date of entrance into force of this act (Act on the Institute for the Study of Totalitarian Regimes, 2007, Art. 14).

10 E.g., in Germany the Victim was allowed to deal with this information within the boundaries of law as he or she wished (Miller, 1998; Danielson, 2004). Meanwhile, in Bulgaria, a person who accessed the Files and wishes to receive copies, gets the copies with information erased regarding former collaborator or other third person when there is no explicit written consent given by these persons or their heirs to reveal their name in the copy of the document. A person also signs a declaration that he or she will be silent about the circumstances that he or she found out. The criminal liability is established for the breach of this obligation (COMDOS, 2015). 
collaborator. ${ }^{11}$ However in all cases the identity of collaborator is established.

Under the model of full access, former collaborators are also able to access the Files concerning them. ${ }^{12}$ Some countries also allow provision of additional materials and statement concerning the information stored about a person in the Files. Such materials are kept as an integral part of the Files and are produced together with the relevant Files if the request is made for the information about such a person (for Slovakia, see Nation's Memory Act, 2000, Art. 23, Para. 2).

Question of legacy of the repressive past also concerns public abilities to access the Files as effective transition is possible only when society reflects its repressive past (Van Boven, 1993; Bassiouni, 2006). Therefore the countries of full access model provide access not only to affected persons but also to any person. In such cases, the necessity to reconcile public interest in knowledge and protection of privacy rights must be particularly addressed.

In Germany, this issue was solved assuming that decision to collaborate means waiver of personal right to privacy (Markovits, 2001). This was especially true for persons who wished to take official positions after transition from

11 In Slovakia, the Victim is able to access all the Files that have been kept about him/ her, including the identity of collaborator if the fact of collaboration is established under special procedure. Such personal data as the date of birth and residence, data on private and family life or data concerning criminal activity, health and property condition are not provided (Nation's Memory Act, 2000, Art. 17, Para. 1; Art. 19; Art. 23, Para. 1; Art. 24). Here additional remark must be given to the fact that under special procedure there is a possibility to exclude certain Files from the disclosure by a proposal of the Slovak Information Service (a central intelligence and security service of the Slovak Republic) or the Ministry of Defense of the Slovak Republic that is made to a committee of the National Council of the Slovak Republic (Nation's Memory Act, 2000, Art. 6). Therefore, Slovakia can be described as a country providing full access subject to the fact that excluded documents do not affect a Victim's ability to access the related information in the Files, including the identity of collaborators. Unfortunately, it was not possible to research further on this issue due to language barrier.

12 In Germany, persons who collaborated with Stasi were able to access their personal files but the information was provided without the identity of any victim to avoid the possibility of their intimidation and respecting their right to privacy (Danielson, 2004; González-Quintana, 2009). In Slovakia, former collaborators will have no right to obtain personal data in these Files only concerning Victims not related to collaborator's former activities (Nation's Memory Act, 2000, Art. 23, Para. 1). In Bulgaria, the collaborators are entitled to examine their Files if the fact of their collaboration was established by the Committee for disclosing the documents and announcing affiliation of Bulgarian citizens to the State Security and intelligence services of the Bulgarian National Army (COMDOS, 2015). 
the repressive past (Markovits, 2001; Danielson, 2004). However, in the case of Victims, issues of privacy are considered and particular attention is given to the protection of Victims' privacy rights. Additionally, attention is paid to the protection of third person's personal data (Halmai, 2007). ${ }^{13}$ Nevertheless, such policy faces criticism. The requirement of complete privacy of Victims in cases when Files are accessed by other persons, as it is in Germany, has hindered scholarly research and development of different approaches towards the communist past (Markovits, 2001).

The full access model is favored for the Victim's ability to know the identity of collaborator (Miller, 1998; Danielson, 2004; González-Quintana, 2009), stating that personal clarification is the urgent prerequisite in reckoning with the past (Miller, 1998). Moreover, in Germany, revealing the names of collaborators has not resulted in massive retaliation and the previous fears did not appear to be true (Markovits, 2001; Danielson, 2004). No data on cases of massive retaliation is possible to obtain concerning other countries where the full access model was implemented. However such disclosure hurts the existing social relations as collaborators "were discovered in families, networks of friends, at the work place and in social organizations" (Karstedt, 1998). This is especially true in cases of dismissal of former collaborators from certain employment positions, the so-called lustration (Miller, 1998; Karstedt, 1998). The process was called selective and failing to reach justice. ${ }^{14}$ Notwithstanding criticism, the full access model is still perceived as a meaningful activity because the society is released from suspicions and groundless fears despite the fact that for certain people the revelation of their collaboration is uncomfortable (Danielson, 2004).

13 In the case of Germany, the information concerning other victims, not related to the Victim, requesting information, was not provided, i.e. the person could access his own file but not the file of others (Miller, 1998; Danielson, 2004; González-Quintana, 2009). In Slovakia, the name and surname of other victim is revealed but no data will be provided concerning the date of birth and residence, data on private and family life or data concerning criminal activity, health and property condition (Nation's Memory Act, 2000, Art. 23, Para. 1). In Bulgaria, personal data will be revealed only through direct examination of the documents and no such data will appear in the copies if there is no written consent given by the person (either victim or collaborator) or his/ her heir. In addition, a person signs a special declaration obliging not to announce the data he or she has found out and criminal liability is established for the breach of this obligation (COMDOS, 2015).

14 E.g., in the case of Germany, the functions of authority responsible for the administration of Stasi documents were sometimes misunderstood: employer perceived information about the collaboration as obliging to dismiss a certain person, even though it should have been the employer's decision whether the fact of collaboration, in a way that is established in Stasi documents, should be treated as deserving dismissal (Miller, 1998). 
All three Baltic countries (Latvia, Estonia and Lithuania), as representatives of the limited access model, have different conditions regarding access to the Files. Many Files were transferred to Moscow or destroyed during the transition period in the Baltic States, thus affecting the completeness of the Files. Accordingly, Estonia has almost no Files while in Latvia the Files lack information concerning reliable data on the identity of former collaborators. Meanwhile, Lithuania is considered to have the biggest volume of Files compared to the other Baltic States (Stan, 2009).

The main reasons limiting access to the Files are lustration and national security issues, which are closely related. They gain priority against the right to know the truth. This is particularly true in the case of Lithuania and Poland, where those models share similarities both in regulation and in the history of their adoption. Starting from very limited access to the Files, these countries ended with much more open policy. ${ }^{15}$ Nevertheless, restrictions are still imposed because certain information in the Files is treated as a state secret for various reasons.

In the model of limited access the first restriction faced by the Victim is restriction to access the Files concerning former collaborators who have admitted their collaboration thus restricting the ability to know the identity of collaborators who informed on them. ${ }^{16}$ The aim of the policy classifying information concerning

15 E.g., in Lithuania the first regulation was introduced in mid-1993 allowing certain groups of victims, i.e. former political prisoners and deportees, to access their criminal and deportation cases containing no classified information, i.e. no data about former collaborators, including their identity, was accessible to the victims. Although this restriction was lifted in 1996, under Resolution of the Government No. 452 previously classified information was accessible only to the employees of State security department, Ministry of Internal Affairs, the Prosecutor's Office, the Courts and the Centre for the Research of the Genocide of the Lithuanian Population and Resistance Movement, performing prescribed tasks, see Government of the Republic of Lithuania, 1993a,b; 1996. Only in 2005, the new regulation was introduced, providing the ability to access the Files if a person was under supervision of these former secret services subject to the information gathered on him or her, see Law on Documents and Archives, Art. 20; and Government of the Republic of Lithuania, 2005.

16 E.g., lustration in Lithuania was started in 2000 when lustration law entered into force. According to current regulation, all information about the persons who had admitted secret collaboration with the former USSR secret services (Lithuanian SSR subdivision of the former USSR State Security Committee (KGB), the Lithuanian SSR Ministry of the Interior and other special services which operated on the territory of Lithuania during the period of 1940-1991) is classified information (Law on Lustration, 1999, Arts. 7 \& 8). In Poland, information about a person who has admitted its former collaboration by producing vetting declaration under special procedure is unavailable ether (Act on the Institute of National Remembrance, 1998, Art. 39, Sections 2, 2a, 2b \& 4). 
the former collaborators who had confessed is the protection of these persons from possible illegal recruitment based on blackmail and threats in the security services of other countries or from inclusion in other illegal activities which are defined as national security issues (e.g., Law on Lustration, 1999, Art. 1; Art. 8, Para. 2). The second argument for limited access to the Files is the decision of authorized institutions that the disclosure of certain Files might pose a threat to national security. ${ }^{17}$

Former collaborators are also provided the right to access the information concerning them in the Files. ${ }^{18}$ As in the case of the model of full access, some countries allow collaborators to make supplements, corrections, updates, explanations and provide additional documents about their collaboration that are kept together with the Files concerning them (e.g., in Poland, Act on the Institute of National Remembrance, 1998, Art. 35b).

Public access to the Files under the model of limited access may be subject to various restrictions. ${ }^{19}$ One is that public access is possible only concerning

17 Such regulation is imposed in Poland, i.e. a Victim will be unable to access the Files because of the decision by the head of the Internal Security Agency, the head of the Intelligence Agency or the Minister of National Defence to keep certain information as classified information for the interests of state security (Act on the Institute of National Remembrance, 1998, Art. 39, Section 1). In Hungary, certain Files are also classified and are in the disposition of the National Security Services, thus limiting ability for a Victim to access them. However secret owners must review the File every three year and the duty to check the reasonableness of keeping such information as classified exists. If these documents cease to be classified, they are transferred to and become available at the Historical Archives of the Hungarian State Security. In Romania, the situation is even more complicated. Although the right for the Victim to access the Files was recognized in 1999, at the same time it was and still is hindered by the lack of the enforcement of legal regulation providing access. Various public institutions responsible for national security, including Romanian Intelligence Service, the Foreign Intelligence Service, the Ministry of National Defence and others, as depositories of Securitate (i.e. former state security institution under communist rule in Romania) Files, are reluctant to transfer these Files to the National Council for the Study of the Securitate Archives, finding justification for their inaction in the broad definition of national security, thus making access almost impossible (Petrescu, 2007; Dobrincu, 2012; Stan, 2013). In Lithuania and Poland, former collaborators are able to access the Files on the same conditions as the Victims. Concerning Lithuania see Law on Documents and Archives, 2012, Arts. 19 \& 20; Government of the Republic of Lithuania, 2007. Concerning Poland, see Act on the Institute of National Remembrance, 1998, Art. 35b. E.g., in Lithuania the general rule allowing access to the Files for everybody was introduced only in 2007, while previous regulation restricted this access to the Files for 70 years from the date of the creation of the certain file (Law on Documents and Archives, 2004, Art. 20; Law on Documents and Archives, 2012). However, the access for scholarly research was possible under certain formal conditions (Government of the Republic of Lithuania, 2005, Art. 7). 
information about persons in the position of certain public offices. ${ }^{20}$

Another restriction is that no public access to the Files that are classified is provided. But even in the limited access model there are exceptions when information cannot be treated as a state secret: in cases a person holds certain public office (for Lithuania, see Law on Lustration, 1999, Art. 7, Para. 2) or the Files contain information about the commitment in international crimes (for Lithuania, see Law on Lustration, 1999, Art. 8, Para. 2; for Poland, see Act on the Institute of National Remembrance, 1998, Art. 39a). Nevertheless, there is no possibility to control whether Files containing information about international crimes, especially those committed during Soviet occupation, are declassified because, except for certain public institutions, there is no access to the Files that are classified. Therefore it could be assumed that such limitations might be incompatible with the public interest as possible barriers for prosecution of collaborators responsible for the commitment of international crimes could be found (Van Boven, 1993; Miller, 1998; González-Quintana, 2009). Moreover, in this case the Victim is also deterred from his/her right to have standing in criminal proceedings concerning his/her victimization (Aldana-Pindell, 2002).

Additional drawback of the limited access model is the right of the Victim to express his/her will in limiting access to the Files containing the information about the Victim on certain conditions. ${ }^{21}$ This exception is usually introduced with an aim to protect Victims' right to privacy. ${ }^{22}$

Assuming that open policy towards Files builds confidence in society and in the state after the repressive past (Danielson, 2004), certain questions emerge concerning the rationality of limited access model. Is such state interference

20 E.g., concerning Poland see Act on the disclosure of information, 2006, Art. 22, Para. 1. It is noticeable that such regulation results in ceaseless changes to the list of public offices that give general access to the Files concerning the person occupying that office.

21 In Lithuania, Victims are allowed to express their will to limit the use of information about them up to their death. They are allowed to limit access in whole or to provide access with his or her consent. See Law on Documents and Archives, 2012, Art. 20 , Para. 3; Government of the Republic of Lithuania, 2007. In Poland, a Victim can makes a special declaration that Files concerning him or her are not accessible for the purposes of academic research or publication up to 50 years from the date of their creation. Special attention is given to the particular personal data, i.e. ethnic or racial origin, religious beliefs, data concerning health and sexual life, and material status. These data cannot be disclosed if a person, either a Victim or a collaborator, has made such a request (Act on the Institute of National Remembrance, 1998, Art. 37).

22 This was particularly stated in Lithuania (Seimas, 2007). 
compatible with the aims of democratic state and obligation for respect of human rights? Are these limitations compatible with the right to personal autonomy protected as a part of the private life? Is national security, the undeniable right of a state, really under threat in democratic society if the irreversible repressive past is disclosed? These questions are even more puzzling as there is no data that states applying the model of full access face bigger challenges in their societies or towards their security.

Here the following remarks could be made. Under the full access model, the Victim is in the position to decide himself/herself whether to find out about the past or not and is able to act within the frames of law concerning the knowledge gained. Meanwhile this ability is lost under the model of limited access as the state decides in advance and gives the only option of no access to certain Files. This means that the person loses his/her ability to act within the frames of law concerning the knowledge gained. It is indisputable that the scale of state interference in such a case is far from that under the communist regime; nevertheless, the interference exists.

Thus, in the limited access model, while limiting access to the Files, the state protection of the interests is not sufficiently grounded as it is based on the presumption that limitation prevents possible retaliation and confrontation of society thus helping to build trust. However, it is evident that all post-communist countries face similar problems concerning the structure of society and trust in society independently from the model applied (Hayoz et al., 2011). ${ }^{23}$ This suggests that reasons of confrontation in the society and lack of trust should be searched elsewhere. Undoubtedly, in case of disclosure of Files, there is a high probability that existing social relations might be damaged. Nevertheless, an incomplete disclosure leaves space for suspicions and speculations in society for an indefinite time on the issue whether a person, especially a public one, was a collaborator or not. Within the personal field, the question - was it my friend, colleague, or relative who informed on me-always remains open. It follows that trust in society cannot be created in such atmosphere.

The model of limited access is also based on the state's right to protect national security and, as a result, certain Files are treated as a state secret. Certain information that was secret under the repressive regime remains secret in a democratic society, although to significantly lesser extent. In a landmark case concerning secret surveillance, Klass and others v. Germany [1978] No. 5029/71, the ECtHR made it clear that "powers of secret surveillance of citizens are

23 Particular attention in this book was given to the works of Valentina Dimitrova-Grajzl, Krzysztof Brzechczyn, François Ruegg, and Alexander Kiossev. 
tolerable under [the European Convention on Human Rights] only in so far as strictly necessary for safeguarding the democratic institution in a democratic society". Therefore it is possible to draw a conclusion that secret surveillance is a last resort in protection of national security in a democratic society. This also raises a question of the soundness of limited access model.

Taking into account all the arguments that have been made in favour of the model of full access, this issue, nevertheless, requires separate research with particular attention to the scope of privacy rights and possible interference to them in a democratic society. This should be done in the light of the case law of ECtHR, as many states that have undergone transition from the communist to the democratic regime are now participants of the European Convention on Human Rights. ${ }^{24}$

\section{Conclusions}

Repressions under the communist regime are treated as international crimes and gross human rights violations if certain required conditions are established. Condemnation of the communist regime is already clearly expressed by historians, lawyers, academics and various international, non-governmental organizations and institutions such as the European Council and the European Court of Human Rights.

The turn from criminal prosecution towards victims' perspective on international fora revealed the importance of truth in addressing human rights' abuses and resulted in naming it as the primary demand of the victims, as only the truth can ensure the restoration of justice and reconciliation of society.

With the enactment of the Basic Principles in 2005, the Victim's right to know the truth together with access to justice and reparations constitute the right to effective remedy. Although the right to know the truth is not clearly established as a separate right in legally binding international documents, there is a growing recognition that it is closely related to the other fundamental human rights and usually is a prerequisite for the Victim to guarantee his/her human rights.

Of special importance to the disclosure of truth is access to the Files as they are evidence of gross human rights violations. However, it is inevitable that a conflict between the right to access and the right to privacy that must be either balanced with a public interest in reconstruction of a democratic state exists.

24 The authors of this article are currently working on the issue. 
Analysis of the practices of states that have undergone transition from the repressive communist regime towards democracy shows that states apply different level of access towards the Files, and two models-full access and limited access ones - are applied in practice.

Germany (together with Bulgaria, the Czech Republic, and Slovakia) is an example of full access model where the identity of collaborators is revealed, while in Lithuania (as well as in Estonia, Latvia, Poland, Hungary and Romania), the access is limited because certain Files are kept as classified information and these limitations concern people who have confessed their collaboration with former secret services. Declassification of such information is treated as a threat to national security. However, all states respect the Victim's right to protect his/her personal identification data and a person is usually authorized to access information about him or her without disclosing personal data about other victims.

Taking everything into account, the model of limited access provides no personal autonomy to decide whether to search the past or not and what to do with the knowledge gained within the frames of law. Society is left in the continuing atmosphere of suspicion and the issue of national security is highly questionable as secret surveillance is a means of last resort in protection of national security in a democratic society.

This gives priority to the model of full access despite of the inconveniences for the persons who collaborated with former secret services because of the disclosure, since this model does not have the abovementioned drawbacks. The experience of countries applying full access model shows that disclosure could be managed effectively including issues of the privacy rights.

However, different means and policies in providing access to the Archives raise the question which standard should be applied for accessing the Files. But the answer to this question is beyond the scope of this article as it requires separate research on the issue of the privacy right as it is elaborated by the case law of the European Court of Human Rights.

Edita Gruodyte is tenure professor and Vice-Dean for Research at the Faculty of Law of Vytautas Magnus University, Kaunas, Lithuania, with 16 years of academic and scientific experience. She is the author of more than 30 articles and a co-author of several books. Gruodyte is also a practising attorney. Her main spheres of academic interest are European criminal law, property, economic, financial and business crimes, and drug crimes.

Silvija Gervienè is a doctoral candidate and assistant at the Department of Public Law of the Vytautas Magnus University. Her doctoral thesis is prepared on the issue of reparations 
for international crimes concerning the period of Soviet occupation. Her main spheres of academic interest are international public and criminal law, human rights and legal ethics. She has co-authored several scientific articles and participated as a younger researcher in the scientific project on legal ethics, implemented at the Faculty of Law of the Vytautas Magnus University.

\section{References}

Act on the disclosure of information... (2006), Ustawa z dnia 18 października $2006 \mathrm{r}$. o ujawnianiu informacji o dokumentach organów bezpieczeństwa państwa z lat 1944-1990 oraz treści tych dokumentów [Act on the disclosure of information on documents of state security agencies from the period between the years 1944-1990 and the content of such documents], 18 October 2006. Retrieved from http://ipn.gov.pl/en/about-the-institute/documents/institute-documents/act-on-thedisclosure-of-information [accessed 9 Jan 2015]

Act on the Institute of National Remembrance (1998), Ustawa z dnia 18 grudnia $1998 \mathrm{r}$. o Instytucie Pamięci Narodowej - Komisji Ścigania Zbrodni przeciwko Narodowi Polskiemu ('Act on the Institute of National Remembrance - Commission for the Prosecution of Crimes against the Polish Nation, December 18, 1998)'. Retrieved from http://ipn.gov.pl/en/about-the-institute/documents/institute-documents/theact-on-the-institute-of-national-remembrance [accessed 15 Oct 2014]

Act on the Institute for the Study of Totalitarian Regimes (2007), Zákon č. 181/2007 Sb., o Ústavu pro studium totalitních režimů a o Archivu bezpečnostních složek a o změně některých zákonů [Act on the Institute for the Study of Totalitarian Regimes and the Security Services Archive, and on Amendments of some Acts], 181/2007 Coll., 8 June 2007. Retrieved from http://www.ustrcr.cz/data/pdf/normy/act1812007.pdf [accessed 9 Jan 2015]

Aldana-Pindell, R. (2002), 'In vindication of justifiable victims' rights to truth and justice for state-sponsored crimes,' Vanderbilt Journal of Transnational Law, vol. 35 , no. 5 , pp. $1399-1501$.

Antkowiak, T. M. (2002), 'Truth as right and remedy in international human rights experience,' Michigan Journal of International Law, vol. 23 (Summer), pp. 977-1013.

Anušauskas, A.; Bubnys, A. \& Kuodytè, D. et al. (2007), Lietuva 1940-1990 (Lithuania 1940-1990), Vilnius: Lietuvos gyventojų genocido ir rezistencijos tyrimo centras.

Anušauskas, A.; Zabiela, V. \& Raudeliūnas, V., eds. (2002), Antikomunistinis kongresas ir tarptautinio Vilniaus visuomenininio tribunolo procesas: "Komunizmo nusikaltimu ivertinimas", 2000 [Anticommunist congress and the process in Vilnius public international tribunal: "Evaluation of the crimes of communism", 2000], Vilnius: Ramona. 
Basic Principles (2005), Basic Principles and Guidelines on the Right to a Remedy and Reparation for Victims of Gross Violations of International Human Rights Law and Serious Violations of International Humanitarian Law, adopted and proclaimed by General Assembly resolution 60/147 of 16 December 2005, No. A/RES/60/147. Retrieved from http://www.ohchr.org/EN/ProfessionalInterest/ Pages/RemedyAndReparation.aspx [accessed 15 Oct 2014]

Banisar, D. (2013), 'Public Oversight and National Security: Comparative Approaches to Freedom of Information,' in M. Caparini \& H. Born (eds.) Democratic Control of Intelligence Services: Containing Rogue Elephants, Hampshire: Ashgate Publishing, pp. 217-235.

Bassiouni, M. C. (2006), 'International recognition of victims' rights,' Human Rights Law Review, vol. 6, no. 2, pp. 203-279. http://dx.doi.org/10.1093/hrlr/ngl009

BIC (2009), 'Coming to terms with the 20th century totalitarian past,' Behind the Iron Curtain, Review of the Institute for the Study of Totalitarian Regimes, no. 1/2009, pp. 8-10. Retrieved from http://www.ustrcr.cz/data/pdf/publikace/bic/bic01-0810.pdf [accessed 31 Jan 2015]

Buyse, A. (2008), 'Lost and regained? Restitution as a remedy for human rights violations in the context of international law,' Heidelberg Journal of International Law (Zeitschrift für ausländisches öffentliches Recht und Völkerrecht), vol. 68, pp. 129-153.

Ciorciari, J. D. (2012), Archiving Memory after Mass Atrocities, Austin: The Bernard and Audre Rapoport Center for Human Rights and Justice.

COMDOS (2015), 'You have the right,' Committee for Disclosing the Documents and Announcing Affiliation of Bulgarian Citizens to the State Security and Intelligence Services of the Bulgarian National Army. Retrieved from http://www.comdos.bg/ Имате_право [accessed 9 Jan 2015]

Commission on Human Rights (2006), Promotion and Protection of Human Rights. Study on the right to the truth. Report of the Office of the United Nations High Commissioner for Human Rights, E/CN.4/2006/91. Retrieved from http://www. un.org/en/ga/search/view_doc.asp?symbol=E/CN.4/2006/91 [accessed 15 Oct 2014]

Council of Europe (1996), Resolution No. 1096 (1996) on measures to dismantle the heritage of former communist totalitarian systems, Parliamentary Assembly, Council of Europe. Retrieved from http://assembly.coe.int/main.asp?Link=/ documents/adoptedtext/ta96/eres1096.htm [accessed 9 Jan 2015]

(2006), Resolution No. 1481 on need for international condemnation of crimes of totalitarian communist regimes, Parliamentary Assembly, Council of Europe. Retrieved from http://assembly.coe.int/main.asp?link=/documents/adoptedtext/ ta06/eres 1481.htm [accessed 9 Jan 2015] 
Courtois, S.; Panné, J.-L. \& Paczkowski, A. et al. (1999), The Black Book of Communism: Crimes, Terror, Repression, transl. \& ed. by J. Murphy and M. Kramer, Cambridge: Harvard University Press.

Damsa, L. (2011), 'Lustration (administrative justice) and closure in post-communist East Central Europe', International Journal of Public Law and Policy, vol. 1, no. 4, pp. 335-375. http://dx.doi.org/10.1504/IJPLAP.2011.044991

Danielson, E. S. (2004), 'Privacy rights and the rights of political victims: implications of the German experience,' The American Archivist, vol. 67 (Fall/Winter), pp. 176-193.

David, R. \& Choi Yuk-ping, S. (2005), 'Victims of transitional justice: lessons from the reparation of human rights abuses in the Czech Republic,' Human Rights Quarterly, vol. 27, no. 2, pp. 392-435. http://dx.doi.org/10.1353/hrq.2005.0016

David, V. (2014), 'The expanding right to an effective remedy: common developments at the Human Rights Committee and the Inter-American Court,' The British Journal of Legal Studies, vol. 3, no. 1, pp. 259-286. Retrieved from http:/www.bcu.ac.uk/ law/research/centre-for-american-studies/british-journal-american-legal-studies/ current-issue [accessed 9 Jan 2015]

Delfi.lt (2014) 'Prokuratūra siūlo ịkalinti buvusị ministrą M. Misiukonị dèl A. KraujelioSiaubūno žüties' [It is suggested by the prosecutor office to imprison former minister M. Misiukonis as criminally liable for the destruction of A. KraujalisSiaubūnas], Delfi.lt, 24 September 2014. Retrieved from http://www.delfi.lt/news/ daily/lithuania/prokuratura-siulo-ikalinti-buvusi-ministra-m-misiukoni-del-akraujelio-siaubuno-zuties.d?id=65936510 [accessed 24 Sep 2014]

Dobrincu, D. (2012), 'A brief history of Romanian archive access since 1989,' transl. by S. Cotter, Euxeinos, vol. 3, pp. 18-25. Retrieved from http://www.gce.unisg. $\mathrm{ch} / \mathrm{en} /$ euxeinos/archives/2012 [accessed 9 Jan 2015]

Freeman, M. (2000-2002), 'Transitional justice: fundamental goals and unavoidable complications,' Manitoba Law Journal, vol. 28, no. 1, pp. 113-121.

González-Quintana, A. (2009), Archival Policies in the Protection of Human Rights, transl. by M. Turner, Paris: International Council on Archives.

Guisse, E. H. \& Joinet, L. (1993), Progress Report on the Question of the Impunity of Perpetrators of Human Rights Violations (Symbol E/CN.4/SUB.2/1993/6). Retrieved from http://documents-dds-ny.un.org/doc/UNDOC/GEN/G93/143/00/ img/G9314300.pdf?OpenElement [accessed 9 Jan 2015]

Halmai, G. (2007), 'Lustration and access to the files in Central Europe,' in V. Dvořáková \& A. Milardovic (eds.) Lustration and Consolidation of Democracy and the Rule of Law in Central and Eastern Europe, Zagreb: Political Science Research Centre, pp. 19-46.

Hansen, T. O. (2013), 'Establishing a normative framework for evaluating diverse cases of transitional justice,' International Studies Journal, vol. 36(9), no. 4, pp. 173-224. 
Hartvigsen, M. (2013), Land Reform in Central and Eastern Europe after 1989 and its Outcome in Form of Farm Structures and Land Fragmentation, FAO Land Tenure Working Paper 24. Retrieved from http://www.fao.org/nr/tenure/infores/lttpapers/ en/ [accessed 9 Jan 2015]

Hayoz, N.; Koleva, D. \& Jesień, L. (2011), 20 Years After the Collapse of Communism: Expectations, Achievements and Disillusions of 1989, Bern: Peter Lang.

Hoffmann, T. (2013), 'Trying communism through international criminal law?: the experiences of the Hungarian historical justice trials,' in K. J. Heller \& G. Simpson (eds.) The Hidden Histories of War Crimes Trials, Oxford: Oxford University Press, pp. 229-247.

Inkuša, K. (2009), 'Mass deportations of 1949 in Latvia as a crime against humanity-a fair legal reality for social and political groups in the context of the Genocide Convention,' Baltic Yearbook of International Law, vol. 9, pp. 69-94.

Karstedt, S. (1998), 'Coming to terms with the past in Germany after 1945 and 1989: public judgments on procedures and justice,' Law\&Policy, vol. 20, no. 1, pp. 15-56. http://dx.doi.org/10.1111/1467-9930.00041

Klass and others v. Germany [1978], ECHR, no. 5029/71.

Kolk and Kislyiy v. Estonia (dec.) [2006], ECHR, no. 23052/04 24018/04.

Law on Documents and Archives (2004), Lietuvos Respublikos dokumentu ir archyvu istatymas [Republic of Lithuania Law on Documents and Archives], Valstybès žinios, 1995, No. 107-2389 as amended by the Law Amending the Law on Archives No. IX-2084 of 30 March 2004.

(2012), Lietuvos Respublikos dokumentu ir archyvu istatymas [Republic of Lithuania Law on Documents and Archives], Valstybès žinios, 1995, No. 107-2389 as amended by the Republic of Lithuania Law Amending the Law on Documents and Archives No. XI-2243 of 2 October 2012.

Law on Lustration (1999), Lietuvos Respublikos asmenu, slapta bendradarbiavusiu su buvusios SSRS specialiosiomis tarnybomis, registracijos, prisipažinimo, iskaitos ir prisipažinusiujų apsaugos įstatymas [Republic of Lithuania Law on the Registration, Confession, Entering into Record of the Persons of the Republic of Lithuania Who Engaged Themselves in Secret Collaboration with the Former USSR Special Services and Protection of Those Who Confessed It], Valstybès žinios, 1999, No. 104-2976.

Liivoja, R. (2013), 'Competing histories: Soviet war crimes in the Baltic States,' in K. J. Heller \& G. Simpson (eds.) The Hidden Histories of War Crimes Trials, Oxford: Oxford University Press, pp. 248-266.

Lrt.lt (2014), 'Kauno apygardos teismas atvertè dar vieną bylą dẻl A. RamanauskoVanago nužudymo' [Another case concerning the destruction of A. RamanauskasVanagas is opened at Kaunas Regional Court], 23 September 2014. Retrieved from http://www.lrt.lt/naujienos/lietuvoje/2/66049/kauno_apygardos_teismas_atverte_ dar_viena_byla_del_a._ramanausko-vanago_nuzudymo [accessed 15 Oct 2014] 
Mälksoo, L. (2001), 'Soviet genocide? Communist mass deportations in the Baltic States and international law,' Leiden Journal of International Law, vol. 14, no. 4, pp. 757-787. http://dx.doi.org/10.1017/S0922156501000371

Markovits, I. (2001), 'Selective memory: how the law affects what we remember and forget about the past: the case of East Germany,' Law \& Society Review, vol. 35, no. 3, pp. 516-563. http://dx.doi.org/10.2307/3185395

Mertelsmann, O. \& Rahi-Tamm, A. (2009), 'Soviet mass violence in Estonia revisited,' Journal of Genocide Research, vol. 11, nos. 2-3, pp. 307-322. http://dx.doi.org/ 10.1080/14623520903119001

Miller, J. (1998), 'Settling accounts with a secret police: The German law on the Stasi records,' Europe-Asia Studies, vol. 50, no. 2, pp. 305-330.

http://dx.doi.org/10.1080/09668139808412537

Misiunas, R. J. \& Taagepera, R. (1993), The Baltic States: Years of Dependence, 1940-1990, Berkeley \& Los Angeles: University of California Press.

Nalepa, M. (2010), Skeletons in the Closet: Transitional Justice in Post-Communist Europe, New York: Cambridge University Press.

Nation's Memory Act (2000), Act 553/2002 Coll. on Disclosure of Documents Regarding the Activity of State Security Authorities in the Period 1939-1989 and on Founding the Nation's Memory Institute (Ústav pamäti národa) and on Amending Certain Acts, 19 August 2002. Retrieved from http:/www.upn.gov.sk/ data/pdf/553_2002_en.pdf [accessed 15 Oct 2014]

OAS (1994), Inter-American Convention on Forced Disappearance of Persons, OAS Treaty Series, No. 68, 33 ILM 1429. Retrieved from http://www.oas.org/juridico/ english/treaties/a-60.html [accessed 9 Jan 2015]

Open Society (2013), 'Archives of State Security Service Records,' Open Society. Retrieved from http:/www.opensocietyfoundations.org/sites/default/files/echrjanowiec-annex-20130116.pdf [accessed 9 Jan 2015]

Parlevliet, M. (1998), 'Considering truth. Dealing with a legacy of gross human rights violations,' Netherlands Quarterly of Human Rights, vol. 16, no. 2, pp. 141-174.

Penart v. Estonia (dec.) [2006] ECHR, no. 14685/04.

Petrescu, D. (2007), 'Dilemmas of transitional justice in post-1989 Romania,' in V. Dvořáková \& A. Milardovic (eds.) Lustration and Consolidation of Democracy and the Rule of Law in Central and Eastern Europe, Zagreb: Political Science Research Centre, pp. 127-151.

Rosenberg, W. G. (2001), "Politics in the (Russian) archives: the 'objectivity question', trust, and the limitations of law,' The American Archivist, vol. 64 (Spring/Summer), pp. 78-95.

Seimas (2007), Conclusion of the Legal Department of the Office of the Seimas No. XP - 536(4), 9 November 2007. Retrieved from http://www3.lrs.lt/pls/inter3/ dokpaieska.showdoc_1?p_id=286235\&p_query=\%20Pri\%EBjimas $\% 20$ prie $\% 20$ 
Nacionalinio\%20dokument \%F 8\%20fondo\%20ypatingosios\%20dalies $\% 20$ ribojam $\%$ F8\%20dokument $\%$ F8\&p_tr2=2 [accessed 0 Jan 2015]

Snyder, T. (2010), Bloodlands: Europe between Hitler and Stalin, New York: Basic Books.

Stan, L. (2009), 'The former Soviet Union,' in L. Stan (ed.) Transitional Justice in Eastern Europe and the Former Soviet Union: Reckoning with the Communist Past, Abingdon: Routledge, pp. 222-246.

- (2013), Transitional Justice in Post-Communist Romania: The Politics of Memory, New York: Cambridge University Press.

Streletz, Kessler and Krenz v. Germany [2001] ECHR, no. 34044/96 35532/97 44801/98.

Teitel, R. G. (2000), Transitional Justice, Oxford: Oxford University Press.

'Truth commissions and similar bodies' (2013), [Website] Transitional justice and memory in the European Union. Retrieved from http://www.proyectos.cchs.csic. es/transitionaljustice/content/truth-commissions-and-similar-bodies [accessed 14 Nov 2014]

Van Boven, T. (1993), Study concerning the right to restitution, compensation and rehabilitation for victims of gross violations of human rights and fundamental freedoms (Symbol E/CN.4/Sub.2/1993/8). Retrieved from http://documentsdds-ny.un.org/doc/UNDOC/GEN/G93/141/58/pdf/G9314158.pdf?OpenElement [accessed 9 Jan 2015] 